AperTO - Archivio Istituzionale Open Access dell'Università di Torino

\title{
Pyramidal groups and debt
}

\section{This is the author's manuscript}

Original Citation:

\section{Availability:}

This version is available http://hdl.handle.net/2318/7732

since 2015-12-23T13:13:52Z

Publisher:

Elsevier BV:PO Box 211, 1000 AE Amsterdam Netherlands:011 3120 4853757, 0113120 4853642, 011

Published version:

DOI:10.1016/j.euroecorev.2004.11.001

Terms of use:

Open Access

Anyone can freely access the full text of works made available as "Open Access". Works made available under a Creative Commons license can be used according to the terms and conditions of said license. Use of all other works requires consent of the right holder (author or publisher) if not exempted from copyright protection by the applicable law. 


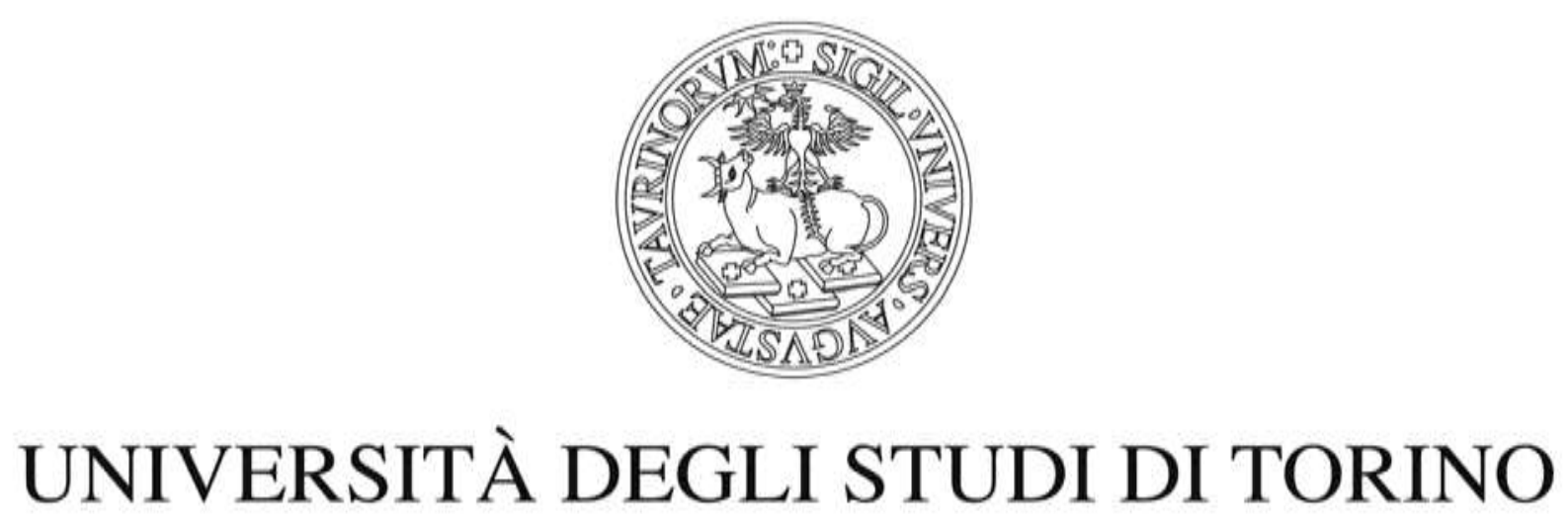

This is an author version Post-Print of the contribution published on:

European Economic Review, Vol.50(4), 2006, p.937-961

DOI: http://10.1016/j.euroecorev.2004.11.001

The definitive version is available at:

http://www.sciencedirect.com/science/article/pii/S0014292104001163 


\section{Pyramidal groups and debt}

September 2004

Magda Bianco*

Bank of Italy, Ufficio Diritto dell’Economia
Giovanna Nicodano**

Università di Torino

\section{ABSTRACT}

This paper suggests that debt should be raised by subsidiaries in order to exploit the limited liability of the holding company. However, when this behavior increases the cost of funds, the holding might prefer to raise debt to a point where it would also default when subsidiaries are insolvent.

After accounting for standard controls, we find that holding companies in Italian pyramids have higher leverage than subsidiaries and that the cash flow share of the entrepreneur in the subsidiary does not play a significant role. These findings are consistent with the implications of our model of group capital structure.

Keywords: capital structure, business groups, bankruptcy, internal capital market, limited liability. JEL Classification Number: G32; K22; P59; D82

* The views expressed in this paper are those of the authors and do not involve the responsibility of the Bank of Italy.

** Corresponding author: Giovanna Nicodano, giovanna.nicodano@unito.it, Facoltà di Economia, Corso Unione Sovietica 218bis, 10134 Torino, phone (39)011-6706073 fax (39)011-6706062

We are grateful to the late Bruce Smith, Arnoud Boot, Luigi Buzzacchi, Gabriella Chiesa, Jurgen Dennert, Marina Di Giacomo, Mara Faccio, Szusanna Fluck, Bruno Parigi, Enrico Perotti, Rafael Repullo, Alessandro Sembenelli, to participants in the ESSFM at Studienzentrum Gerzensee, the EEA and EARIE, Tor Vergata VIII Financial Conference, and in seminars at CEMFI, Ente Einaudi, University of Freiburg, Padova and Torino for useful suggestions. Giovanna Nicodano is also indebted to CEMFI, the Tinbergen Institute and the University of Haifa for hospitality, and to MURST for funding. The usual disclaimer applies. 


\section{Introduction}

Business groups are a common corporate organizational form in several continental European and developing countries ${ }^{1}$. Frequently, they have a pyramidal structure with a holding company at the top and various layers of subsidiaries below. The entrepreneur typically has the majority of voting rights in every company, either directly in the holding or indirectly in the subsidiaries. A major source of finance for groups is debt, yet no model of pyramids explains how debt is chosen and allocated across group-affiliated companies. This paper investigates theoretically group capital structure and its welfare implications, and empirically how debt is allocated within Italian groups.

Traditional capital structure theories refer to a stand-alone company. However the capital structure of group-affiliated companies is richer since they have access to both the internal (within the group) and the external capital market. This structure might be affected, among other factors, by the law: in major jurisdictions the holding has indeed no obligation for the insolvency of its operating subsidiaries, unless it is proved that it was directly responsible, i.e., the holding enjoys limited liability ${ }^{2}$. Our model builds specifically on this insight - previously ignored in the corporate finance or business group literature - suggesting that subsidiaries should raise a large fraction of group debt, since limited liability insures the holding company from costly bankruptcy in adverse contingencies. However, if lenders cannot monitor the risk of projects, the entrepreneur may allocate riskier projects in the operating unit. Anticipating this, lenders might charge higher interest rates. It may therefore pay the entrepreneur to commit not to increase excessively the risk taken by subsidiaries by raising the holding company's debt to such a level that it would default together with the operating unit when the latter is insolvent

See Barca and Becht (2002) for Europe and Khanna (2000) for developing countries.

See Blumberg (1989) for the US, Hadden (1996) on Britain, France, Germany and the US, and Libonati (1996) on Italy. Limited liability for the holding company sometimes requires that the subsidiary is not fully owned by the group. 
Most of the literature on pyramidal groups emphasizes the agency problem between the group controlling agent and subsidiaries' minority shareholders, associated with the low share of cash-flow that the entrepreneur is entitled to in operating subsidiaries and hence with the opportunities for their expropriation (Bebchuk, 1999; Bebchuk et al., 2000). While these theories rationalize why stock markets are underdeveloped in countries where pyramidal groups are common, they cannot explain why banking sectors are well developed in the same countries. In other words, they explain the costs of pyramidal structures but not their potential advantages. By focusing on the relationship with lenders, we take a first step in this last direction ${ }^{3}$.

Our empirical analysis concerns group affiliated Italian companies, for which unconsolidated accounts are available. Thanks to these data - usually not available through major commercial data providers - we are able to distinguish between external debt, obtained from outside-the-group financiers only, and total loans obtained from other group-affiliated units. Hence our empirical analysis focuses on each company's external debt ${ }^{4}$. This is related to the entrepreneur's cash-flow share and to the type - holding or operating subsidiary - of company, while controlling for firm specific factors affecting its comparative advantage in raising debt. Our results are consistent with the predictions of the model, as we find that holding companies raise a larger portion of external debt over assets while other capital structure theories bear different implications.

The paper is organized as follows. The details of the model are presented in section 2 . Section 3 contrasts the implications of previous capital structure theories with those of our model. In section 4 we present the empirical analysis.

3 For analyses of investments in internal capital markets, see a topic which which maters for both conglemerates (Gertner, Scharfstein and Stein, 1994; Stein, 1997 and ;-Rajan et al., 2000, for conglomerates and -greups (Perotti and Gelfer, 2001 for groups.

Empirical studies of capital structure (Rajan and Zingales, 1995; Faccio et al, 2000; Booth et al. 2001) use consolidated accounts when investigating companies with subsidiaries, thus by-passing the issue of the allocation of debt among them. An exception is Piga (2002). Research on groups addresses tunneling (Bertrand et al., 2002), takeovers (Boehmer, 2000), company discount (Cornell and Liu, 2001), managerial turnover (Franks and Mayer, 2001; Volpin, 2002), diversification and risk sharing (Khanna and Yafeh, 2001; Khanna and Palepu, 2000) and liquidity constraints (Schiantarelli and Sembenelli, 2000). 


\section{A model of debt financing in group-affiliated companies.}

\subsection{The set -up.}

The group is composed of a holding and an operating subsidiary, indexed by $j=1,2$. The former can start one investment project, whereas the latter has an option to two alternative projects. The cash-flow from running the holding company project is $\pi_{1 \mathrm{k}}$, where $\mathrm{k}=\mathrm{H}, \mathrm{L}$ indicates the level of realized cash-flow in the high and low profitability states respectively. Cash-flow in the holding is equal to $\pi_{1 \mathrm{H}}>0$ with probability $\mathrm{p}$ and to $\pi_{1 \mathrm{~L}}=0$ with probability (1-p). Similarly, the subsidiary's cash flow is equal to $\pi_{2 \mathrm{Hi}}>0$ with probability $\mathrm{q}_{\mathrm{i}}$ and 0 with probability $\left(1-\mathrm{q}_{\mathrm{i}}\right)^{5}$. The subscript $\mathrm{i}=\{\mathrm{s}, \mathrm{r}\}$ indexes the safer and riskier investment projects respectively.

The entrepreneur's cash flow share in each company is equal to $c_{j}$. We analyze the case of no outside equity $\left(c_{1}=c_{2}=1\right)$ as well as the typical case for groups $\left(1 \geq c_{1}>c_{2}>0\right)$, where outside equity is larger in the operating unit. All agents are risk neutral, and there is free entry in banking.

Assumption 1: limited liability. The holding company enjoys limited liability, i.e., the subsidiary's lenders cannot claim the holding's assets. This is the only crucial characteristic identifying the holding in our model. ${ }^{6}$

Assumption 2: dissipative bankruptcy. The holding company’s bankruptcy destroys an amount y $>0$ of resources. This represents the entrepreneur's investment in asset specific human capital, that is lost if the firm is liquidated. The size of these losses in the real world will depend on the features of bankruptcy law?

\footnotetext{
These probabilities are conditional on publicly available information. We do not model superior information on investment opportunities enjoyed by the entrepreneur, which has already been emphasized by Stein (1997).

Personal limited liability is relevant for capital structure in a stand-alone company (Hellwig,1981). Our insight - so far ignored in corporate finance - concerns corporate limited liability, which is also shown to affect product market strategies by Cestone and Fumagalli (2004).

They are larger when enforcement of creditors' rights is strict. This makes it more difficult to keep a profitable enterprise in distress as a going concern. Enforcement is strict and the debtor loses control in several countries where business groups are common, such as Germany, France and Italy (Rajan and Zingales, 1995, p.1446-47).
} 
Foregone private benefits of control are one way to represent bankruptcy costs: we choose it here because both Nicodano (1998) and Volpin (2002) find that private benefits in Italian holding companies are positive and Dyck and Zingales (2004) -argue that they are large in the international comparisons ${ }^{8}$.

Assumption 3: cross-subsidies. The entrepreneur can shift cash flows across the group and decides the proportion of debt, $\alpha$, which is raised by the operating subsidiary. This assumption is at odds with company law requiring firm directors and managers to behave in the best interest of firm's shareholders rather than of the group's entrepreneur. However this legal restriction is not fully enforced in major jurisdictions (Hadden, 1996). Indeed, cash flows can be transferred in a variety of ways. The firm needing a cash transfer may get an internal loan; and/or obtain resources and materials at below-market prices; and/or sell assets to another group company.

Assumption 4: equity rationing. An amount $\mathrm{D}$ of external resources must be raised through debt in order to finance group investment projects, because raising all outside financing as equity capital is not possible. This restriction can be ascribed to agency problems between the entrepreneur and minority shareholders - as in Hellman and Stiglitz (2000); and/or to coordination problems among entrepreneurs leading to a low liquidity trap in the stock market- as in Pagano (1993).

Assumption 5: cash flows from the riskier and the safer project in the subsidiary. The riskier project is less likely to have positive cash-flow: $\mathrm{q}_{\mathrm{s}}>\mathrm{q}_{\mathrm{r}}$. However, its cash-flow is larger conditional on being positive: $\pi_{2 \mathrm{Hs}}<\pi_{2 \mathrm{Hr}}$. Finally the expected cash flow from the riskier project is higher:

$$
\pi_{2 H \mathrm{~s}} \mathrm{q}_{\mathrm{s}}-\pi_{2 \mathrm{Hr}} \mathrm{q}_{\mathrm{r}}=\Delta<0
$$

This assumption ensures that the riskier project is not dominated by the safer one. At the same time, the higher expected cash flow from the riskier project does not imply that it is preferred by a risk neutral entrepreneur, because bankruptcy costs must be accounted for.

Assumption 6: the (relevant) state space consists of four states $\{\mathrm{HH}, \mathrm{LL}, \mathrm{HL}, \mathrm{LH}\}$, where the first 
letter refers to the holding company and the second one to the subsidiary. In state HH group cashflow exceeds group debt, as specified by the following equation:

(2) $\mathrm{D}<\pi_{2 \mathrm{Hi}}+\pi_{1 \mathrm{H}}, \quad$ for $\mathrm{i}=\{\mathrm{r}, \mathrm{s}\}$.

In state LH the subsidiary's cash flow is sufficient to reimburse group debt, even when the safer project is implemented:

$$
\mathrm{D}<\pi_{2 \mathrm{Hi}}, \quad \text { for } \mathrm{i}=\{\mathrm{r}, \mathrm{s}\} .
$$

In state HL, the positive cash-flow from the holding is lower than group debt:

$$
\mathrm{D}>\pi_{1 \mathrm{H}}
$$

State HL is crucial for our argument in that the holding's limited liability may play a role.

We could consider another state in which the losses of the subsidiary are not so large, in which case the holding company could both lend to and rescue the operating subsidiary. But this state is not essential, so we drop it for simplicity.

Assumption $7 \mathrm{a}(7 \mathrm{~b})$ : lenders are (not) able to monitor project risk.

Assumption 7a can be expected to hold when groups have an "inside" or "main" bank, such as in the German and the Japanese financial system.

\subsection{The first-best capital structure in business groups.}

We now determine a cutoff value for $\alpha$ and an associated interest rate such that, if $\alpha<\alpha_{i}$, in state $\mathrm{H}$ the parent is unable to service its own debt. In other words the holding must receive funds from its subsidiary in order to service its debt in state $\mathrm{HH}$, and goes bankrupt together with the subsidiary in state HL. When $\alpha>\alpha_{i}$, the holding's debt is low enough that it can use its limited liability in state HL.

Lemma 1: assume A7(a). Then the interest factor charged to the holding company is equal to:

$$
1 /\left[p+(1-p) q_{i}\right] \quad \text { if } \alpha \geq \alpha_{i}
$$

$$
\mathrm{R}_{1 \mathrm{i}}(\alpha)=
$$




$$
\left[D(1-\alpha)-p\left(1-q_{i}\right) \pi_{1 H}\right] / D(1-\alpha) q_{i} \quad \text { if } \alpha<\alpha_{i}
$$

and the holding can service its own external debt in state $\mathrm{H}$ so long as it is lower than the cutoff value:

(6)

$$
\left(1-\alpha_{i}^{\prime}\right) D=\left[p+(1-p) q_{i}\right] \pi_{1 H}
$$

The interest factor in the subsidiary is in turn:

$$
\mathrm{R}_{2 \mathrm{i}}=1 / \mathrm{q}_{\mathrm{i}}
$$

Proof:

The risk neutral lender's participation constraint is satisfied if the interest factor ensures zero expected profits, i.e. if it solves:

$$
\begin{array}{ll}
\text { (8) } \quad \mathrm{q}_{i} p R_{1 i} \mathrm{D}(1-\alpha)+(1-\mathrm{p}) \mathrm{q}_{\mathrm{i}} \mathrm{R}_{1 \mathrm{i}} \mathrm{D}(1-\alpha)+\mathrm{p}\left(1-\mathrm{q}_{\mathrm{i}}\right) \pi_{1 \mathrm{H}}=\mathrm{D}(1-\alpha) & \text { if } \alpha<\alpha_{\mathrm{i}} \text { ' } \\
\text { (9) }\left[\mathrm{q}_{\mathrm{i}} \mathrm{p}+(1-\mathrm{p}) \mathrm{q}_{\mathrm{i}}+\left(1-\mathrm{q}_{\mathrm{i}}\right) \mathrm{p}\right](1-\alpha) \mathrm{R}_{1 \mathrm{i}} \mathrm{D}=\mathrm{D}(1-\alpha) & \text { if } \alpha>\alpha_{\mathrm{i}} \text {,. }
\end{array}
$$$$
\text { if } \alpha>\alpha_{i} \text {. }
$$

for the holding company. For the subsidiary:

$$
\left[q_{i} p+(1-p) q_{i}\right] \alpha R_{2 i} D=D \alpha .
$$

The cutoff level of debt for the holding satisfies:

$$
\left(1-\alpha_{i}{ }^{\prime}\right) R_{1 i}\left(\alpha_{i}{ }^{\prime}\right) D=\pi_{1 H}
$$

where $R_{1 i}$ is evaluated at $\alpha_{i}$.

When $\alpha<\alpha_{i}$, the parent defaults in state HL. The interest factor in equation (5) falls in the holding's profits because they are appropriated by lenders in state HL. The risk of projects undertaken by the operating company, captured by $\mathrm{q}_{\mathrm{i}}$, also affects credit conditions in the holding. Lenders charge a higher interest rate to the holding company with a riskier subsidiary because the holding is likelier to default $\left(\mathrm{q}_{\mathrm{r}}<\mathrm{q}_{\mathrm{s}}\right)$. Therefore the holding company can sustain a smaller portion of total debt with its own cash flow, which implies $\alpha_{\mathrm{s}}{ }^{\prime}<\alpha_{\mathrm{r}}$.

It is now possible to show that it pays the entrepreneur to raise debt from the operating company so as to avoid bankruptcy costs by allowing the holding to use limited liability:

Proposition 1 (debt in operating companies with "inside" lenders): assume A7a. Then the 
operating unit raises a large enough portion of group debt $\left(\alpha>\alpha_{i}{ }^{\prime}\right)$ such that the holding company never defaults in state HL.

Proof: The payoff for the entrepreneur when $\alpha>\alpha$ ' is equal to

$$
\begin{aligned}
& p\left[y+c_{1} \pi_{1 H}-R_{1 i} c_{1} D_{1}\right]+(1-p) q_{i}\left[y-R_{1 i} c_{1} D_{1}\right]+q_{i i} c_{2}\left[\pi_{2 H i}-R_{2 i} D_{2}\right]= \\
= & p c_{1} \pi_{1 H}+q_{i} c_{2} \pi_{2 H i}+y\left[p+(1-p) q_{i}\right]-D\left[c_{1}(1-\alpha)+c_{2} \alpha\right]
\end{aligned}
$$

where $D_{1}=(1-\alpha) D$ is debt in the holding, $D_{2}$ is debt in the subsidiary, and (5), (7), (9) are accounted for. The first term in (12) is his/her share of profits net of debt costs plus private benefits from the holding in states $H H$ and $H L$; the second term are private benefits from the holding net of debt costs in state LH; the last term are his/her share of profits in the subsidiary in state LH and $H H$.

The entrepreneur's payoff, when $\alpha<\alpha$, reflects that the holding defaults in state $H L$ because it cannot use limited liability. Hence the first term in (13) below considers net his or her payoff from the holding in state HH only:

$$
\begin{aligned}
& \mathrm{q}_{\mathrm{i}} \mathrm{p}\left[\mathrm{c}_{1} \pi_{1 \mathrm{H}}+\mathrm{y}-\mathrm{R}_{1 \mathrm{i}} \mathrm{c}_{1}\right]+(1-\mathrm{p}) \mathrm{q}_{\mathrm{i}}\left[\mathrm{y}-\mathrm{R}_{1 \mathrm{i}} \mathrm{c}_{1} \mathrm{D}_{1}\right]+\mathrm{q}_{\mathrm{i}} \mathrm{c}_{2}\left[\pi_{2 \mathrm{Hi}}-\mathrm{R}_{2 \mathrm{i}} \mathrm{D}_{2}\right]= \\
= & \mathrm{pc}_{1} \pi_{1 \mathrm{H}}+\mathrm{q}_{\mathrm{i}} \mathrm{c}_{2} \pi_{2 \mathrm{Hi}}+\mathrm{yq}_{\mathrm{i}}-\mathrm{D}\left[\mathrm{c}_{1}(1-\alpha)+\mathrm{c}_{2} \alpha\right]
\end{aligned}
$$

where (5), (7) and (8) are accounted for.

It is easy to check that (12)> (13) since $\mathrm{yp}\left(1-\mathrm{q}_{\mathrm{i}}\right)>0$, which are the private benefits saved in state $H L$ thanks to limited liability. Hence $\left(\alpha>\alpha_{i}^{\prime}\right)$ maximizes the entrepreneur's payoff.

Remark 1: Proposition 1 establishes that the entrepreneur sets $\alpha>\alpha_{i}{ }^{\prime}$ so as to use the holding company's limited liability vis-à-vis inside lenders. On top of this, inspection of (12) reveals that s/he has an incentive to set $\alpha=1$ whenever his or her cash-flow share is lower in the subsidiary than in the holding $\left(c_{1}>c_{2}\right)$. Thus doing, the entrepreneur shifts onto the minority shareholders a larger portion of the interest cost of external debt. This result implies that, if $\alpha>\alpha_{i}{ }^{\prime}$, we should observe a negative correlation between the external debt of group affiliated units and the entrepreneur's cash 
flow share when we examine the data.

Remark 2: In our set up the holding company delivers private benefits from control, while the operating company does not. Moreover, there is one state of nature in which the operating unit is unprofitable and cannot be rescued by the holding company. This remark clarifies that the only asymmetric feature that matters for our results is assumption A1 (limited liability), while asymmetric private benefits and state space are simplifying assumptions. Indeed consider the opposite case, when only the subsidiary yields private benefits from control and there is one state of nature in which the holding is insolvent and cannot be rescued by its subsidiary. Then capital structure is undetermined. In particular, the opposite debt allocation (debt being raised by the holding) is not strictly preferred to any other, because the operating unit is involved in the reorganization anyway - with loss of private benefits - if the holding goes bankrupt. This is because the holding's lenders have an indirect claim on the operating unit's assets.

We now characterize the first best equilibrium.

Proposition 2 (the first best equilibrium): a social planner chooses the safer project (i=s) and larger debt in the operating company $\left(\alpha>\alpha_{s}{ }^{\prime}\right)$ if

$$
\Delta+\mathrm{y}(1-\mathrm{p})\left(\mathrm{q}_{\mathrm{s}}-\mathrm{q}_{\mathrm{r}}\right)>0
$$

Proof: equation (12) and equation (13) evaluated at $c_{1}=c_{2}=1$ measure the aggregate payoff to both the entrepreneur and the minority shareholders, when $\left(\alpha>\alpha_{i}{ }^{\prime}\right)$ and $\left(\alpha<\alpha_{i}{ }^{\prime}\right)$ respectively. It can be checked that (12)>(13) at $c_{1}=c_{2}=1$.

There are then two candidate first-best allocations, both entailing $\left(\alpha>\alpha_{i}{ }^{\prime}\right)$, that differ in the level of risk chosen by the subsidiary. The social planner opts for the safer project if its expected payoff (left-hand side) exceeds the one from the risky project (right-hand side):

$$
\mathrm{p} \pi_{1 \mathrm{H}}+\mathrm{q}_{\mathrm{s}} \pi_{2 \mathrm{Hs}}+\mathrm{y}\left[\mathrm{p}+(1-\mathrm{p}) \mathrm{q}_{\mathrm{s}}\right]>\mathrm{p} \pi_{1 \mathrm{H}}+\mathrm{q}_{\mathrm{r}} \pi_{2 \mathrm{Hr}}+\mathrm{y}\left[\mathrm{p}+(1-\mathrm{p}) \mathrm{q}_{\mathrm{r}}\right]
$$

The first term, on both the left-and right-hand sides, are profits from the holding company in state 
$H H$ and $H L$, the second term are profits from the subsidiary in states $H H$ and $L H$, while the third term are private benefits from control in states $H H, H L$ and LH. It is easy to check that (12) simplifies to (14).

The social planner thus chooses debt in the operating company $\left(\alpha>\alpha_{i}{ }^{\prime}\right)$, since it maximizes both the entrepreneur's payoff and the minority shareholders' profits without affecting the lenders, who always break even. The planner also implements the safer project when the larger cash-flow from the riskier project is more than offset by the increased bankruptcy costs. In the sequel, inequality (14) is assumed to be satisfied, ensuring the optimality of the safer project.

\subsection{Equilibrium capital structure when risk cannot be monitored by lenders.}

The Nash equilibrium needs not coincide with the first best equilibrium when there are no inside lenders, as the following Lemma clarifies:

Lemma 2: assume A7b. Suppose that lenders charge the safe rate of interest $\left(R_{i}=R_{s}\right)$ and that debt is raised by the subsidiary ( $\left.\alpha \geq \alpha_{\mathrm{s}}{ }^{\prime}\right)$. Then the entrepreneur prefers the riskier investment project (i=r) provided that inequality (17) below is satisfied at $\alpha_{\mathrm{s}}$ '. If this is the case, the Nash equilibrium does not coincide with the first best equilibrium. If (17) is not satisfied at $\alpha=1$, then the Nash equilibrium coincides with the first best equilibrium.

Proof: the payoff to the entrepreneur from implementing the riskier project, when the safer interest rate is charged by the outside lenders and $\alpha \geq \alpha_{\mathrm{s}}$, is equal to:

$$
\begin{aligned}
& \mathrm{pc}_{1} \pi_{1 \mathrm{H}}+\mathrm{q}_{\mathrm{r}} \mathrm{c}_{2} \pi_{2 \mathrm{Hr}}+\mathrm{y}\left[\mathrm{p}+(1-\mathrm{p}) \mathrm{q}_{\mathrm{r}}\right]-\mathrm{R}_{1 \mathrm{~s}} \mathrm{c}_{1} \mathrm{D}_{1}\left[\mathrm{p}+(1-\mathrm{p}) \mathrm{q}_{\mathrm{r}}\right]-\mathrm{c}_{2} \mathrm{R}_{2 \mathrm{~s}} \mathrm{D}_{2} \mathrm{q}_{\mathrm{r}}= \\
& \left.=\mathrm{pc}_{1} \pi_{1 \mathrm{H}}+\mathrm{q}_{\mathrm{r}} \mathrm{c}_{2} \pi_{2 \mathrm{Hr}}+\mathrm{y}\left[\mathrm{p}+(1-\mathrm{p}) \mathrm{q}_{\mathrm{r}}\right]-\mathrm{D}\left\{\mathrm{c}_{1}(1-\alpha) \mathrm{x}+\mathrm{c}_{2} \alpha\left(\mathrm{q}_{\mathrm{r}} \mathrm{q}_{\mathrm{s}}\right)\right]\right\}
\end{aligned}
$$

where $\mathrm{x}=\left[(1-\mathrm{p}) \mathrm{q}_{\mathrm{r}}+\mathrm{p}\right] /\left[\mathrm{p}+(1-\mathrm{p}) \mathrm{q}_{\mathrm{s}}\right]<1$.

This must be compared with equation (12) evaluated at $i=s$, which assumes that the entrepreneur 
implements the safer project consistent with the interest rate charged by lenders. So the riskier project is chosen if $(16)<(12)$, i.e. if:

$$
\begin{aligned}
& \left.\mathrm{pc}_{1} \pi_{1 \mathrm{H}}+\mathrm{q}_{\mathrm{r}} \mathrm{c}_{2} \pi_{2 \mathrm{Hr}}+\mathrm{y}\left[\mathrm{p}+(1-\mathrm{p}) \mathrm{q}_{\mathrm{r}}\right]-\mathrm{D}\left\{\mathrm{c}_{1}(1-\alpha) \mathrm{x}+\mathrm{c}_{2} \alpha\left(\mathrm{q}_{\mathrm{r} / \mathrm{q}}\right)\right]\right\}> \\
& \mathrm{pc}_{1} \pi_{1 \mathrm{H}}+\mathrm{q}_{\mathrm{s}} \mathrm{c}_{2} \pi_{2 \mathrm{Hs}}+\mathrm{y}\left[\mathrm{p}+(1-\mathrm{p}) \mathrm{q}_{\mathrm{s}}\right]-\mathrm{D}\left[\mathrm{c}_{1}(1-\alpha)+\mathrm{c}_{2} \alpha\right] \quad \text { that simplifies to: }
\end{aligned}
$$

$$
\mathrm{c}_{2} \Delta+\mathrm{y}(1-\mathrm{p})\left(\mathrm{q}_{\mathrm{s}}-\mathrm{q}_{\mathrm{r}}\right)+\mathrm{D}\left\{\mathrm{c}_{1}(1-\alpha)(\mathrm{x}-1)+\mathrm{c}_{2} \alpha\left[\left(\mathrm{q}_{\mathrm{r}} / \mathrm{q}_{\mathrm{s}}\right)-1\right]\right\}<0
$$

The sum of the first two terms in (17) is positive given that project $s$ is the first best project (from equation 14). The term in curly brackets is negative, and represents the lower cost of debt coming from fooling the lenders. It decreases in $\alpha$ for $c_{1} \geq c_{2}$. So if (17) is satisfied at $\alpha_{\mathrm{s}}$ ', it will be satisfied for all $\alpha>\alpha_{\mathrm{s}}$, in which case the Nash equilibrium is not the first best equilibrium because the entrepreneur prefers the riskier project.

Thus the entrepreneur would implement the riskier investment project in operating companies when net gains from "fooling" the lender are positive. Gains are given by the reduction in the repayment probability, which the outside lender fails to incorporate in the interest rate, and the excess revenue from the riskier project $\left(c_{2} \Delta\right)$, while its cost is the increase in expected bankruptcy costs $y(1-p)\left(q_{s}-q_{r}\right)$ associated with the higher likelihood of the subsidiary being unsuccessful.

This Lemma delivers some counterintuitive insight into the nature of private benefits. These are often considered as welfare reducing by the literature on pyramids, the more so the lower the cash-flow share of the entrepreneur. For instance, large private benefits and low cash-flow shares distort the entrepreneur's investment choices in Bebchuk et al (2000). Our second best analysis delivers a different implication. When banks cannot monitor risk, larger private benefits in the holding and a lower cash flow share in subsidiaries make deviations from the first best allocation less likely, as implicit in equation (17). The reason is that the entrepreneur prefers protecting her private benefits rather than increasing cash flows by implementing riskier projects in the subsidiary. 
Indeed private benefits are lost more often when riskier projects are chosen because the probability of subsidiary's success is lower.

When the Nash equilibrium does not coincide with the first best, then there are two other candidate equilibrium allocations. In the first, the risky project is implemented, lenders charge the higher interest rate and debt in the subsidiary exceeds $\alpha_{r}$. This is sub-optimal in that the operating company is insolvent too often relative to the first best. In the other candidate equilibrium, $\alpha$ falls below $\alpha_{s}^{\prime}$ thus impeding the holding company's limited liability.

Proposition 3 (second best equilibrium with "outside" lenders): assume A7b and (17) satisfied at $\alpha_{\mathrm{s}}$ '. Then the equilibrium is characterized by (a) a small share of group debt in the operating company, the safer project in the subsidiary and the safer interest rate charged by lenders $\left\{\alpha<\alpha_{\mathrm{s}}{ }^{\prime}\right.$; $\left.\mathrm{i}=\mathrm{s} ; \mathrm{R}_{\mathrm{i}}=\mathrm{R}_{\mathrm{s}}\right\}$ if both (20) and (22) hold; (b) it is characterized by $\left\{\alpha \geq \alpha_{\mathrm{r}}\right.$; $\left.\mathrm{i}=\mathrm{r} ; \mathrm{R}_{\mathrm{i}}=\mathrm{R}_{\mathrm{r}}\right\}$ otherwise.

Proof: The entrepreneur's payoffs in the candidate equilibria (a) and (b) are respectively given by equation (13) evaluated at $i=s$ :

$$
\mathrm{pc}_{1} \pi_{1 \mathrm{H}}+\mathrm{q}_{\mathrm{s}} \mathrm{c}_{2} \pi_{2 \mathrm{Hs}}+\mathrm{yq}_{\mathrm{s}}-\mathrm{D}\left[\mathrm{c}_{1}(1-\alpha)+\mathrm{c}_{2} \alpha\right] \text {, and by equation (12), where the holding }
$$
company's limited liability in state HL is accounted for, evaluated at $i=r$ :

$$
\mathrm{pc}_{1} \pi_{1 \mathrm{H}}+\mathrm{q}_{\mathrm{r}} \mathrm{c}_{2} \pi_{2 \mathrm{Hr}}+\mathrm{y}\left[\mathrm{p}+(1-\mathrm{p}) \mathrm{q}_{\mathrm{r}}\right]-\mathrm{D}\left[\mathrm{c}_{1}(1-\alpha)+\mathrm{c}_{2} \alpha\right]
$$

The entrepreneur prefers (a) to (b) only if (18) exceeds (19), that is only if the following inequality holds:

$$
\mathrm{c}_{2} \Delta+\mathrm{y}\left\{\mathrm{q}_{\mathrm{s}}-\left[\mathrm{p}+(1-\mathrm{p}) \mathrm{q}_{\mathrm{r}}\right]\right\}>0
$$

In order for (a) to be an equilibrium, higher debt in the holding must actually serve as a commitment device not to increase risk. This is true only if the entrepreneur's payoff from choosing the riskier project, at $\alpha<\alpha_{s}$ :

$$
\mathrm{q}_{\mathrm{r}} \mathrm{p}\left[\mathrm{c}_{1} \pi_{1 \mathrm{H}}+\mathrm{y}-\left(1+\mathrm{r}_{1 \mathrm{~s}}\right) \mathrm{c}_{1}\right]+\left[\mathrm{y}-\mathrm{R}_{1 \mathrm{~s}} \mathrm{c}_{1} \mathrm{D}_{1}\right](1-\mathrm{p}) \mathrm{q}_{\mathrm{r}}+\mathrm{q}_{\mathrm{r}} \mathrm{c}_{2}\left[\pi_{2 \mathrm{Hr}}-\mathrm{R}_{2 \mathrm{~s}} \mathrm{D}_{2}\right]=
$$




$$
\begin{aligned}
& \mathrm{q}_{\mathrm{r}} \mathrm{pc}_{1} \pi_{1 \mathrm{H}}+\mathrm{q}_{\mathrm{r}} \mathrm{c}_{2} \pi_{2 \mathrm{Hr}}+\mathrm{yq}_{\mathrm{r}}-\mathrm{R}_{1 \mathrm{~s}} \mathrm{c}_{1} \mathrm{D}_{1} \mathrm{q}_{\mathrm{r}}-\mathrm{c}_{2} \mathrm{R}_{2 \mathrm{~s}} \mathrm{D}_{2} \mathrm{q}_{\mathrm{r}}= \\
& =\mathrm{pc}_{1} \pi_{1 \mathrm{H}}\left[\mathrm{q}_{\mathrm{r}}-1+\left(1-\mathrm{q}_{\mathrm{s}}\right)\left(\mathrm{q}_{\mathrm{r}} / \mathrm{q}_{\mathrm{s}}\right)\right]+\mathrm{q}_{\mathrm{r}} \mathrm{c}_{2} \pi_{2 \mathrm{Hr}}+\mathrm{yq} \mathrm{q}_{\mathrm{r}}-\mathrm{D}\left[\mathrm{c}_{1}(1-\alpha)+\mathrm{c}_{2} \alpha\right]\left(\mathrm{q}_{\mathrm{r}} / \mathrm{q}_{\mathrm{s}}\right)
\end{aligned}
$$

is lower than the payoff from choosing the safer project (equation 15). This occurs only if:

$$
-\mathrm{c}_{2} \Delta+\mathrm{y}\left(\mathrm{q}_{\mathrm{r}}-\mathrm{q}_{\mathrm{s}}\right)+\mathrm{pc}_{1} \pi_{1 \mathrm{H}}\left[\left(\mathrm{q}_{\mathrm{r}} / \mathrm{q}_{\mathrm{s}}\right)-1\right]-\mathrm{D}\left\{\left[\mathrm{c}_{1}(1-\alpha)+\mathrm{c}_{2} \alpha\right]\left[\left(\mathrm{q}_{\mathrm{r} /} / \mathrm{q}_{\mathrm{s}}\right)-1\right]\right\}<0 .
$$

Only if both (22) and (20) hold, lenders charge the low-risk rate and the entrepreneur prefers commitment to lower risk for all $\alpha^{9}$. If (20) is violated, the entrepreneur prefers the riskier project even if (22) is satisfied, that is even if s/he could credibly commit to the safer one. Finally, if (22) does not hold, debt in the holding is not a credible commitment not to increase risk. Thus lenders charge the high-risk rate no matter where debt is located. It follows that the entrepreneur prefers debt in the subsidiary - which minimizes the loss of private benefits - and the riskier investment project even if (20) holds. ${ }^{10}$

Figure 1 summarizes the equilibrium allocations of debt. In the following section we contrast their implications with those of competing theories.

\section{External debt in group-affiliated companies}

The capital structure literature does not explicitly address the issue of debt allocation in business groups (see, for example, Harris and Raviv, 1991). In this section we discuss the implications of some existing theories, as well as those of our model of group borrowing.

H1. The managerial discipline hypothesis: External debt is higher in operating than in holding companies and is negatively correlated with the entrepreneur's cash-flow share. Debt is a disciplining device for managers when there is separation of ownership from control, and satisfying also (17) and (14).

11 It could be argued that holding companies can write guarantee letters in favor of subsidiaries' lenders, so as to avoid a costlier commitment. Such letters cannot however substitute for external debt in holding companies as a commitment device, because they are legally unenforceable contracts. Their existence has been explained as a welfare- 
managerial objectives differ from shareholders' (Jensen and Meckling, 1976). In a business group the entrepreneur usually owns larger equity stakes in holding companies and is often the CEO. Hence debt should be higher in subsidiaries, which are often run by managers without equity stakes.

H2. The holding's limited liability hypothesis: External debt is higher in operating units and is negatively correlated with the entrepreneur's cash-flow share. In our model the entrepreneur chooses the amount of group debt to be raised by the holding company and by its operating unit from external financiers. S/he also chooses the risk level characterizing the investment project of the operating unit, which cannot be observed by the lender. Two features of the model are crucial. The first is the limited liability enjoyed by the holding company vis-à-vis the debt obligations of the operating unit. The second is costly bankruptcy. In this framework raising external debt from the operating unit gives the entrepreneur the option of avoiding group bankruptcy by letting the single operating unit go bankrupt, when it is insolvent. This hypothesis correspond to two equilibrium allocations in our model, namely the first best equilibrium (Proposition 2 and Lemma 2) and the second best equilibrium (b) of Proposition 3.

H3. Commitment to lower risk hypothesis: External debt is higher in holding companies and the correlation between external debt and the entrepreneur's cash-flow share is non-negative. Since an outside lender charges a higher interest rate when the holding company is protected against the default in operating units (because s/he anticipates the potential increase in risk), it may pay the entrepreneur to commit not to increase risk in operating units. This is achieved by having the holding company raise a sufficiently high amount of external debt that the holding goes bankrupt together with the subsidiary, when the latter is insolvent. This hypothesis corresponds to the second best equilibrium allocation (a) of Proposition 3.

H4. The Irrelevance Hypothesis: Holding and operating companies do not show systematic differences in external debt, when other firm's characteristics are controlled for. Traditional capital 
structure theories, surveyed by Harris and Raviv (1991), suggest that several firm characteristics such as profitability and collateral - affect firm capital structure. Once such factors are controlled for, however, company type should not matter.

\section{Empirical analysis}

We now explore how debt is allocated across companies in a sample of Italian groups, controlling for other firm characteristics.

\subsection{Sample description}

Our samples consist of two cross-sections of group affiliated joint-stock companies for the years 1992 and 1996. Each is obtained by matching two data sets. The first contains information provided by listed companies to the Italian stock market supervisory authority (CoNSoB). Corporate law mandates that shareholdings exceeding 2 per cent of outstanding equity be reported to CoNSoB. Furthermore all equity stakes larger than 10 per cent, which are held by a listed company, must be disclosed. Group structure is reconstructed in two ways through such reports. The first is through the explicit information about control relationships reported to CoNSoB by each listed company. The second is through the use of algorithms which - on the basis of shareholders' stakes - identify the existence of control relationships (such as $51 \%$ voting rights) when not explicitly stated. These data thus depict the pyramidal structure of all "listed groups", which include at least one listed company.

Data include all shareholders of listed companies with holdings larger than 2 per cent and all listed companies' shareholdings exceeding 10 per cent. We are therefore able to construct the "cash flow share", as the sum that is actually invested in the company by the entrepreneur divided by total equity capital. This variable is computed by accounting for the controlling agent's direct and 
indirect shareholdings along the control chain. For example, if agent A controls company B with a 50 per cent share and B controls company $\mathrm{C}$ with a 50 per cent share, the cash flow share of $\mathrm{A}$ in $\mathrm{C}$ is 25 per cent ${ }^{11}$. The original data set has information on approximately 4.000 companies, but we exclude listed and unlisted companies not belonging to a group and those without a code that allows a match with balance sheet data: the result for 1996 is 2611 observations.

The second data set (Centrale dei Bilanci) reports balance sheet information for approximately 30.000 Italian joint-stock companies. From this we retrieve information on firm's total debt and credit, and in particular on both bank debt and internal debt, i.e. debt towards other companies in the group. Unfortunately, no information is available on the interest rate applied on bank loans or on loans received through the internal capital market.

We exclude from our sample bank holding companies and insurance companies, since their liabilities are not directly comparable to the debt issued by non-financial firms. Industrial groups in Italy do not include a "main bank" as in Japan or Germany. However they may include operating firms specializing in leasing and factoring, which we identify in the regressions through dummies. We also include state-owned companies, that might have been subject to political pressures and whose debt was guaranteed by the state. In the regression analysis we distinguish between financial and non-financial operating companies, and between state-owned and privately held companies.

Table 1 presents summary statistics concerning our sample. The number of group-affiliated firms for which we also have balance sheet information is 728 for 1996 (700 for 1992). They belong to 95 (101) groups. Our data sources classify them as holding companies when their main activity is to hold shares of other companies in the group. In our sample 86 (117) are holding companies, 573 (528) are operating companies outside the financial sector and 69 (55) are operating companies in the financial sector (leasing, factoring ). In 1996 the mean number of companies per group is 35, of which $20.5 \%$ are listed.

11 For details on this variable and its value in Italian listed companies, see Bianchi et al. (2002). 
While our sample contains almost all listed companies, it only has information on $33.3 \%$ of companies per group. This is because Centrale dei Bilanci reports balance sheets for a sample (not the universe) of Italian joint-stock companies. Moreover it does not cover partnerships. Finally, some_joint stock companies might also be excluded by us because of a mismatch of their fiscal identification code between our data sources. We are not able to obtain any information concerning the characteristics of excluded partnerships. However, we find some information about 515 joint stock companies not present in the Centrale dei Bilanci sample with a different data provider (Cerved). These are quite small, in that they have $11 \%$ of mean debt and $10 \%$ of mean assets of our 728 companies. Thus our sample is biased towards larger joint-stock companies. This bias is likely to be smaller than in most empirical studies of capital structure, that focus on listed joint stock companies only. Moreover, leverage of excluded joint stock companies is comparable in size to that of the companies included in our data set. Thus sample selection bias is unlikely to affect our inference, as far as the capital structure choice of joint stock companies is concerned.

We consider three measures of debt financing (scaled with total assets): total financial debt (debt for short), bank debt and net external debt. The first one includes debt financing from all sources - including financial companies as well as bond issues. The second one is the conventional measure of bank debt. The third one is the difference between debt and total financial credit from sources outside the group. It is the best approximation to the "external financing needs" that matter in theoretical models. Columns (a) and (b), referring to the whole sample in 1996, show that both holding and financial companies have higher debt ratios (.27 and .35$)$ than operating subsidiaries (.16). The same is true for bank debt (.17 and .19 versus .12) and for net external debt (.31 and .19 versus .15). A similar pattern emerges for private companies in columns (c) and (d). We discuss the 1992 figures in section 4.3.

So as to complete the picture of group capital structure we also measure net internal debt as the difference between financial debt and financial credit towards firms belonging to the same 
group. Holding companies are net lenders to subsidiaries (-0.07) while both financial and operating companies are net borrowers $\left(0.02\right.$ and 0.07 respectively).$^{12}$

Firm profitability is measured by its return on investment (net profits plus interest payments scaled by the sum of financial debt and equity). The numerator accounts for both operating income and income from financial assets. We prefer this measure to operating income which could underestimate the profitability of holding companies, whose major source of revenues is financial operations. Holding companies show a markedly lower profitability than operating companies, which - as we discuss in section 4.4 - is accompanied by moderately lower profit volatility.

In Table 1, we also distinguish operating units with minority shareholders. These may suffer from risk shifting more than other subsidiaries, because they are not fully owned by their direct parent. As a consequence the upstream company enjoys limited liability. ${ }^{13}$ Moreover, the cash flow share of the entrepreneur is decreasing as we proceed from holding companies to financial and non financial operating companies, and reaches a minimum for companies which are not fully owned by their direct parent. For both reasons one may expect them to have higher debt than other operating companies, if $\mathrm{H} 2$ prevails. Descriptive statistics show that they tend to have higher (bank and/or net external) debt than other operating companies.

Finally, the share of non-financial assets - which can be pledged as collateral - is very low for holding companies (4.16) while it is much larger for operating companies (19.59).

\subsection{Regression results}

The results of the regression analysis for the year 1996 are displayed in Table 2. The dependent variable is net external financial debt over total assets, as this captures borrowing from

12 More than $50 \%$ of companies in our sample do not borrow internally, as revealed by median internal debt being equal to zero. However, a relevant portion of companies uses the internal capital market: firms with either positive internal debt and/or positive internal credit account for $80 \%$ of asset value.

These companies are also subject to legal restrictions, because company law requires firm directors and managers to behave in the best interest of firm's shareholders rather than of the group's entrepreneur. However there have been cases where courts accepted as valid operations performed in the interest of the group as a whole. 
outside-the-group lenders. The use of the book value of debt plus equity as a scaling variable leads to qualitatively similar results (slightly different point estimates, equal statistical significance) that are not reported.

The theoretical hypotheses summarized in section 2 refer to the allocation of debt within each pyramid, hence we introduce group dummies. "Financial" and "operating" are dummy variables which distinguish such types of firms from holding companies. We also consider "listed" companies as potentially special, since they are subject to stricter stock market monitoring and disclosure requirements. This may reduce the cost of credit by increasing the firm's bargaining power with banks and/or overcome borrowing constraints (Pagano,Panetta, Zingales, 1998).

Firm size (measured as the log of total assets), profits (ROI) and non financial assets (NFA) are control variables, common in the literature on capital structure (Rajan and Zingales, 1995). We cannot include a measure of market risk since not all companies are listed.

We report in column A results for all groups, in column B we exclude groups for which we have only one observation; in column $\mathrm{C}$ we also exclude state owned firms, and in the last column we eliminate financial operating companies. Results are stronger for privately held firms, although qualitatively similar for the whole sample.

The regression analysis confirms that, even after controlling for profitability, size, etc., holding companies have more external debt than (operating and financial) subsidiaries. Higher leverage in holding companies is not consistent with either the managerial discipline $\mathrm{H} 1$, or the irrelevance $\mathrm{H} 4$ or the limited liability hypotheses $\mathrm{H} 2$. However, it is consistent with $\mathrm{H} 3$, the commitment to lower risk hypothesis.

The lack of explanatory power of the cash-flow share points to the absence of a disciplining role for external debt, against H1. It also seems to rule out the shifting of interest payments onto the minority shareholders of operating companies, which would occur under the limited liability 
hypothesis (see Remark 1 to Proposition 1). Indeed, both hypotheses imply a negative correlation between external debt and the cash-flow share.

The coefficient of the dummy "minority*operating", indicating operating companies with minority shareholders, is not significantly different from zero. This finding again runs counter the limited liability hypothesis H2. Overall, the commitment to lower risk hypothesis (H3) through larger debt in holding companies is the only surviving hypothesis. Their larger debt exposure also confirms the specificity of holding companies that have been shown to be characterized by lower managerial turnover (Volpin, 2002) as well as higher voting premium (Nicodano, 1998) than their operating subsidiaries.

For what concerns other control variables, size is usually positively related to external debt implying that larger companies raise more funds, possibly because of stronger bargaining power and hence better credit conditions. Profits (ROI) are negatively correlated with external leverage, as in previous empirical work on capital structure (Fama and French, 2002; Harris and Raviv, 1991, p. 337). Listed companies show lower levels of external debt than other firms, against our priors. We therefore interpret this result as being driven by lower demand for external debt by listed companies, which take the opportunity to reduce leverage - as in Pagano, Panetta and Zingales (1998).

The share of tangible assets should be positively correlated with the ability to raise external debt, because collateral makes it costlier for the entrepreneur to increase risk, thus reducing the expected cost of insolvency to the lender (Stiglitz and Weiss, 1981; Hellman and Stiglitz, 2000; Bester, 1985). Its coefficient turns out to be positive, but it is never statistically different from zero.

Taxes are another well-known determinant of capital structure. Here we do not control for tax rates as there was no difference across group-affiliated units in the sample period. Taxes were levied on each company without consolidation of group profits ${ }^{14}$. The total tax burden could have

Double taxation of dividends was avoided through a tax credit mechanism. 
been reduced only if units with positive income before taxes artificially raised their deductible costs to the benefit of units with negative income before taxes, for example by borrowing at higher-thanmarket-rates from units with negative income (interest expenses are deductible). This might have induced a positive correlation between profits before taxes and internal debt, while the relationship with external debt is less obvious. Econometric results do not change when we substitute ROI with ROI before taxes as regressor, with the new variable slightly more significant than ROI. We also checked for an asymmetric value of debt as tax shield by inserting a dummy variable that is equal to 1 when profit before taxes is positive. However, it does not add any explanatory power.

The above regressions do not distinguish among industries. However, there may be systematic differences in leverage across industries (Harris and Raviv, 1991, p.334), due to their systematic risk and their unequal possibility to engage in asset substitution. To check for this we introduce industry dummies which capture each operating company's main industry. The results (available from the authors) suggest that the negative coefficients of the operating company dummies in Table 2 are determined by companies in some industrial sectors, where most of the operating companies in our sample operate.

\subsection{Robustness over time: regression results prior to the Ferruzzi insolvency}

A large Italian group, Ferruzzi-Montedison, became insolvent in 1993. This event may be relevant to our analysis as the restructuring implied a large transfer of value from creditor of operating companies to those of the holding. Hence we check whether the data support H3 also prior to this insolvency, in 1992.

Italian banks mostly lent to the holding company, while foreign banks' lending was concentrated with the operating companies at the bottom of the pyramid among which Montedison was the largest one. Foreign debt accounted for $56 \%$ of Montedison bank debt in the lower layers of the pyramid, but only for $8.9 \%$ of the holding company debt. Creditors of Montedison lost $10 \%$ of 
their exposure in the restructuring, while an Italian bank became the largest shareholder of the holding company with an estimated gain of $\$ 2 b n^{15}$.

Descriptive statistics for the year 1992 (Table 1, last four columns) point to a change in leverage between 92 and 96. Net external debt increases for holding companies - especially for private ones - and decreases for both financial and operating companies. These differences suggest a potential structural break, even if they are not statistically significant.

We therefore run the same regression on our 1992 sample. Consistent with H3, the coefficient of the operating company dummy is negative already in 1992 (Table 3), but significant only for the full sample, i.e., not for private firms only. The entrepreneur's cash-flow share is statistically significant and positive, against $\mathrm{H} 1$ and $\mathrm{H} 2$, meaning that debt was mainly allocated to the holding company and to the subsidiaries "closer" to the holding companies rather than to the most distant ones. This offers some evidence that the equilibrium-with-commitment prevailing in 1996 was already in place in $1992^{16}$.

\subsection{Robustness to specification changes}

A further explanation for the higher leverage observed in holding companies is their lower risk that may make lenders more willing to provide funds ${ }^{17}$. Indeed, risk can be lower in parent companies than in subsidiaries' because the former resemble diversified portfolios.

In order to check for the role of risk on the allocation of debt we resorted to another database (Cerved), which provides only a small subset of balance sheet figures for all joint stock companies: from this we obtained information on profits (ROI) for the previous years and computed volatility as

15 See Penati and Zingales, 2000.

The coefficient of financial operating companies is not statistically different from zero and minority shareholders in operating companies seem to bear a larger share of external debt, as revealed by the positive coefficient of the dummy variable Operating* Minority. These changes in point estimates between 1996 and 1992 are never statistically significant.

$17 \quad$ Booth et al. (2000); Kale et al. (1991). 
the standard deviation of profits over 5 years ${ }^{18}$. Volatility is indeed smaller for holding than operating companies both in the full sample (5.08 versus 6.24$)$ and in private groups (4.88 versus $6.26)$.

The regression analysis on this set of data, including also volatility, is reported in Table 4. This new explanatory variable is not statistically significant and has a positive sign. All estimates are less efficient due to the loss in the number of observations. However, the financial and the operating company dummies retain statistical significance in the sample of private companies, and are close to statistical significance in the whole sample. Thus the inclusion of volatility does not change the picture obtained on the 1996 data: groups allocate a larger portion of their net external debt in holding companies.

\section{Concluding comments}

The literature on business groups has so far focused on the potential expropriation of minority shareholders by entrepreneurs in countries characterized by weak investor protection. This paper contributes to understanding pyramids by shifting the focus of the analysis from equity to debt, which is their main source of external funds. It also allows to clarify the role of the holding company's limited liability, which is a feature of the law governing business groups in major jurisdictions.

Our model stresses that limited liability of the holding company may reduce bankruptcy costs by allowing for partial default of unsuccessful operating units. Protecting some units from the failure of other units is welfare improving, and this improvement is increasing in the size of bankruptcy costs. This implication might be tested in a cross-section of countries: pyramidal structures should be more valuable relative to alternative organizational forms, and hence more common, where bankruptcy procedures are costlier.

18 The size of our original sample is no longer sufficient as less than half of companies are included every year. 
Our empirical analysis sheds light on capital structure in group affiliated companies. In our sample holding companies raise a larger portion of external debt over assets and are net lenders to their subsidiaries. Furthermore, the correlation between company's external debt and the entrepreneur's cash flow share is positive, when statistically significant. This evidence is inconsistent with other theories of capital structure, which imply either larger debt in operating units or the irrelevance of group capital structure. This pattern mirrors instead one equilibrium of our model, where the entrepreneur commits not to increase risk in subsidiaries by levering up the holding company - thus giving up her option of rescuing the holding from the default of operating subsidiaries.

Empirical studies of capital structure usually focus on the consolidated balance sheets of listed companies. We extended the analysis to unlisted group-affiliated firms. However, smaller joint-stock companies as well as partnerships are not covered by our data sources. Further research could challenge the robustness of our findings on the basis of larger data-sets which may be available in other countries. Information concerning interest rates paid by holding and operating companies may also help to further discriminate among competing hypotheses concerning group capital structure. 


\section{References}

Barca F. and M. Becht eds., 2001. The Control of Corporate Europe, (Oxford University Press).

Bebchuk, L. A., 1999. A rent protection theory of corporate ownership and control. NBER WP n. 7203.

Bebchuk, L. A., Kraakman R., Triantis, G., 2000. Stock pyramids, cross ownership and dual class equity: the creation and agency costs of separating control from cash flow rights, in: R. Morck , ed., Concentrated Corporate Ownership (University of Chicago Press and NBER) 295-315.

Bertrand, M., Mehto, P., Mullainathan, Sendhil, 2002. Ferreting out tunnelling: an application to Indian business groups. Quarterly Journal of Economics,117, 121-148.

Bester, H., 1985. Screening versus rationing in credit markets with imperfect information. American Economic Review, 75, 850-855.

Bianchi, M., Bianco, M., Enriques, L. 2002. Ownership, pyramidal groups and separation between ownership and control in Italy, in: Barca, F., Becht, M., eds., The control of corporate Europe (Oxford University Press, Oxford).

Blumberg, P.I., 1989. The Law of Corporate Groups (Little, Brown and Company, Boston).

Boehmer, E.., 2000. Business Groups, Bank Control, and Large Shareholders: An Analysis of German Takeovers. Journal of Financial Intermediation, 9, 117-148.

Boot, A.W., Greenbaum, S.I., Thakor, A.J., 1993. Reputation and discretion in firm contracting. American Economic Review, 83, 1165-83.

Booth, L., Aivazian, V., Demirguc-Kunt, A., Maksimovic, V., 2001. Capital structures in developing countries. The Journal of Finance, 56, 87-130.

Cestone G., Fumagalli C., 2004. The Strategic Impact of Resource Flexibility in Business Groups, Rand Journal of Economics, forthcoming.

Cornell, B., Liu, Qaio., 2001. The parent group puzzle: when is the whole less than one of the parts? 
Journal of Corporate Finance,7, 341-366.

Dewenter , K., Novaes, W., Pettway, R.H., 2001. Visibility versus complexity in business groups: evidence from Japanese Keiretsu. Journal of Business, 74, 79-100.

Dyck, A., L. Zingales (2004), Private benefits of control: an international comparison, Journal of Finance, 537-600.

Faccio, M., Lang, L. and Young, L., 2000. Debt, agency costs and institutions. University of Notre Dame.

Fama E.F., French K.R., 2002. Testing Trade-Off and Pecking Order Predictions About Dividends and Debt, Review of Financial Studies, 15, 1-33.

Franks J., Mayer, C., 2001. Ownership and control of German corporations. Review of Financial Studies, 14, 943-977.

Gertner, R.H., Scharfstein, D.S., Stein, J., 1994. Internal versus external capital markets. Quarterly Journal of Economics, 109, 1211-1230.

Hadden, T., 1996. Liabilities in corporate groups, in: G. Rossi ed., Atti del Convegno sui Gruppi organizzato dalla Rivista delle Società, novembre 1995 (Giuffrè, Milano).

Harris, M., Raviv, A., 1991. The theory of capital structure. The Journal of Finance, 46, 297-335.

Hellmann, T., Stiglitz, J.E., 2000. Credit and equity rationing in markets with adverse selection, European Economic Review, 44, 281-304.

Hellwig, M., 1981. Limited Liability and the Modigliani Miller Theorem. American Economic Review, 71, 155-170.

Jensen, M., Meckling W., 1976. Theory of the Firm: Managerial Behavior, Agency Costs, and Capital Structure. Journal of Financial Economics, 3, 305-360.

Kale, J., Noe, T.H., Ramirez, G.G., 1991. The effect of business risk on corporate capital structure: theory and evidence. Journal of Finance, 46, 1693-1715.

Khanna, T., 2000. Business groups and social welfare in emerging markets: existing evidence \& 
unanswered questions. European Economic Review, 44, 748-761.

Khanna, T., Palepu, K., 2000. Is group affiliation profitable in emerging markets? An analysis of diversified Indian business groups. Journal of Finance, 55, 867-891.

Khanna, T., Yafeh, Y., Business Groups and Risk Sharing around the World, www.ssrn.com, 2001

La Porta, R., Lopez de Silanes, F., Shleifer, A., Vishny, R. 1999. Corporate ownership around the world. Journal of Finance, 54, 471-517.

Libonati, B., 1996. Responsabilità della capogruppo, degli amministratori, delle varie società, in: G. Rossi, ed., Atti del Convegno sui Gruppi organizzato dalla Rivista delle Società, novembre 1995 (Giuffrè, Milano).

Nicodano, G., 1998. Business groups, dual-class shares and the value of the voting right. Journal of Banking and Finance, 22, 1117-37.

Pagano, M., 1993. The flotation of companies in the stock market: a coordination failure model. European Economic Review, 37, 1101-25.

Pagano, M., Panetta, F., Zingales, L., 1998. Why Do Companies Go Public? An Empirical Analysis. Journal of Finance, 53, 27-64.

Penati, A., Zingales, L. 2000. Efficiency and distribution in financial restructuring: the case of the Ferruzzi group. www.ssrn.com.

Perotti, E.C., Gelfer S., 2001. Red barons or robber barons? Governance and investment in Russian financial--industrial groups. European Economic Review, 45, 1601-17.

Piga, C. A.G., Debt and Firms' Relationship: The Italian Evidence, Review of Industrial Organization, 20, 2002, 267-282.

Rajan, R., Zingales, L., 1995. What do we know about capital structure? Some evidence from international data. Journal of Finance, 50, 1421-1460.

Rajan, R., Servaes. H., Zingales, L., 2000. The cost of diversity: the diversification discount and inefficient investment. Journal of Finance, 55, 35-80. 
Schiantarelli, F., Sembenelli, A., 2000. Form of ownership and financing constraints: panel data evidence from flow of fund and investment equations. Empirica, 27, 175-192.

Stein, J.C., 1997. Internal capital markets and the competition for corporate resources. The Journal of Finance, 52, 111-133.

Stiglitz, J.E., Weiss, A., 1981. Credit rationing in markets with imperfect information. American Economic Review, 71, 393-411.

Volpin, P.F., 2002. Governance with poor investor protection: evidence from top executive turnover in Italy. Journal of Financial Economics, 64, 61-90. 


\section{FIGURE 1}

This figure describes the equilibrium allocations of the model, assuming that the cash flow share of the entrepreneur is larger in the holding company. In state HL the holding is profitable and the subsidiary is not (as indicated by the first and second subscripts, respectively). $\alpha$ is the proportion of group external debt allocated to the subsidiary and $\alpha_{i}^{\prime}$ is a cutoff value such that, for $\alpha<\alpha_{i}^{\prime}$, the holding goes bankrupt in state HL. The interest factor is $\mathrm{R}_{\mathrm{i}}$. The risk of the investment project in the subsidiary is indicated by $\mathrm{i}$, which is either equal to $\mathrm{r}$ (riskier) or $\mathrm{s}$ (safer). The implications of each equilibrium configurations are listed in the left-hand side column.

\section{FIRST BEST EQUILIBRIUM}

- $\quad$ larger debt in subsidiaries

$\left\{\alpha>\alpha_{\mathrm{s}}{ }^{\prime} ; \mathrm{R}_{\mathrm{i}}=\mathrm{R}_{\mathrm{s}} ; \mathrm{i}=\mathrm{s}\right\}$

- negative correlation cash-flow share and deb

\section{EQUILIBRIUM WITH COMMITMENT NOT TO INCREASE RISK}

- $\quad$ larger debt in the holding

- $\quad$ non-negative correlation between cash-flow share and debt $\left\{\alpha<\alpha_{\mathrm{s}}{ }^{\prime} ; \mathrm{R}_{\mathrm{i}}=\mathrm{R}_{\mathrm{s}} ; \mathrm{i}=\mathrm{s}\right\}$

The holding is bankrupt too often. In particular, it is insolvent in state HL because it needs a transfer from a successful subsidiary in order to service its debt, which is "too high" since $\alpha<\alpha_{\mathrm{s}}$ '. Limited liability is not exploited. However, the safer project is implemented by the subsidiaty, which is not bankrupt too often. 
Table 1. Summary statistics

Columns (a)-(d) present descriptive statistics for our 1996 sample, while columns (e)-(h) refer to 1992

$\mathrm{N}$. of firms per group: average number of firms belonging to a group, according to the Consob data set.

$\%$ of firms per group in the sample: share of group-affiliated companies, which is included in our sample.

$\%$ of listed companies per group: share of listed companies in each group, according to the Consob data set.

Bank debt: short and long term loans from banks.

Debt: financial loans from all sources (banks, other companies, bonds).

Net external debt: debt net of all financial credit from external sources.

Net internal debt: financial loans from other companies of the group net of financial credit towards companies of the group.

ROI: return on investment; it is computed as the sum of net profits and interest payments, scaled by the sum of equity and financial debt Cash flow share: it is the share of cash-flow owned by the controlling agent in the company

NFA: total non financial assets

1996

N. of firms

N. of firms per group

$\%$ of firms per group in sample

$\%$ of listed firms per group

Debt / Total assets

Holding

Financial Companies

Operating companies

with minority shareholders

Bank debt / Total assets

Holding

Financial Companie

Operating companies:

with minority shareholders

Net external debt / Total assets

Holding

Financial Companies

Operating companies

with minority shareholders

Net internal debt / Total assets

Holding

Financial Companies

Operating companies

with minority shareholders

ROI

Holding

Financial Companies

Operating companies

with minority shareholders

Cash Flow Share

Holding

Financial Companies

Operating companies

with minority shareholders

NFA / Total assets

Holding

Financial Companies

Operating companies

with minority shareholders $\begin{array}{cc}(\mathrm{a}) & (\mathrm{b}) \\ \text { Mean } & \text { Median }\end{array}$

All firms

728

$\begin{array}{cc}35 & 10 \\ 33.3 & 33.3 \\ 20.5 & 9.0 \\ & \\ \mathbf{0 . 1 9} & \mathbf{0 . 1 1} \\ 0.27 & 0 \\ 0.35 & 0 \\ 0.16 & 0 . \\ 0.17 & 0.10\end{array}$

$\begin{array}{cc}\mathbf{0 . 1 3} & \mathbf{0 . 0 5} \\ 0.17 & 0.06 \\ 0.19 & 0.03 \\ 0.12 & 0.04 \\ 0.13 & 0.06\end{array}$

0.17

0.31

0.19

0.15

0.15

0.10

0.28
0.08

0.08
0.09

0.08

$\begin{array}{ll}\mathbf{0 . 0 5} & \mathbf{0 . 0 0} \\ -0.07 & -0.002\end{array}$

$0.02 \quad 0.00$

0.07

6.08

1.71
3.42
7.06

3.42
7.06

8.25

39.26

39.26
48.08

41.98

37.60

34.61

17.18

$\mathbf{1 7 . 1 8}$
4.16
13.31
19.59

19.59
19.24

0.00

6.66

3.82
4.66

4.66
7.79

35.29

50.21

41.82

28.61

9.54

0.20
0.06

12.85

13.02 $\begin{array}{cc}(\mathrm{c}) & (\mathrm{d}) \\ \text { Mean } & \text { Median }\end{array}$

Private firms only

550

36

33.1

22.8

0.2

0.30
0.36
0.18

0.18
0.19

0.15

.15
0.19
0.21
0.13

0.21
0.13

0.15

0.19
0.37

0.37
0.19

0.16
0.18

0.04

$-0.08$

0.03

0.07

7.08
1.89
2.83

2.83

8.50

33.76

45.01

39.43

31.08

30.17
16.8

3.65

10.52

19.89

19.89
19.60

\section{2}

$\begin{array}{cc}(\mathrm{e}) & (\mathrm{f}) \\ \text { Mean } & \text { Median }\end{array}$

(g) (h)

\section{All firms}

$43.52^{700}$

11
31.8
10.1

$\mathbf{0 . 1 4}$
0.26
0.36
0.12
0.14

0.07

0.09
0.08
0.07

0.07
0.09

0.13

0.37

0.10
0.11

0.13

0.00

$-0.004$

0.00
0.00

0.00

6.92
3.82

3.82
4.34
8.17
8.39

26.10

44.06
40.38

25.53

25.41

10.05

10.05
0.24
0.03

0.03
14.79

14.79
15.12
$25.94 \quad 10.00$

$23.56-25.00$

14.29

0.24

$\begin{array}{ll}0.29 & 0.17 \\ 0.24 & 0.24\end{array}$

0.44

0.44
0.21
0.22

0.19

0.22
0.29

0.29
0.18

0.18

0.23

0.30

0.28
0.21

0.22

0.01

-0.13
0.05

0.05
0.04

0.02

4.12

0.89
7.03

4.54

35.62

47.31
37.06

32.86

32.17

18.40

5.84
25.83

25.83
20.41

20.41
19.47
Private firms only

$38.555^{506} 9.00$

$25.83 \quad 25.00$

$24.33 \quad 16.49$

$0.26 \quad 0.20$

$\begin{array}{lll}0.24 & 0.31 & 0.26 \\ 0.33 & 0.45 & 0.37\end{array}$

$\begin{array}{lll}0.16 & 0.23 & 0.18 \\ 0.17 & 0.25 & 0.20\end{array}$

$\begin{array}{lll}0.13 & 0.20 & 0.15\end{array}$

$\begin{array}{lll}0.14 & 0.21 & 0.15 \\ 0.17 & 0.27 & 0.19\end{array}$

$\begin{array}{lll}0.17 & 0.27 & 0.19\end{array}$

$\begin{array}{lll}0.13 & 0.19 & 0.15 \\ 0.14 & 0.20 & 0.16\end{array}$

$\begin{array}{lll}0.16 & 0.26 & 0.20\end{array}$

$\begin{array}{lll}0.23 & 0.31 & 0.28\end{array}$

$\begin{array}{lll}0.15 & 0.24 & 0.19\end{array}$

$\begin{array}{lll}0.17 & 0.25 & 0.20\end{array}$

$\mathbf{0 . 0 0} \quad-\mathbf{0 . 0 0 2}$

0.00

$\begin{array}{rrr}-0.06 & -0.13 & -0.04 \\ 0.00 & 0.01 & 0.00\end{array}$

$\begin{array}{lll}0.00 & 0.01 & 0.00 \\ 0.00 & 0.03 & 0.00\end{array}$

$\begin{array}{lll}0.00 & 0.01 & 0.00 \\ 0.00\end{array}$

$\begin{array}{lll}6.50 & 4.56 & 6.74\end{array}$

$\begin{array}{lll}5.22 & 0.99 & 5.02 \\ 7.34 & 7.73 & 7.73\end{array}$

$\begin{array}{lll}6.88 & 5.11 & 7.07\end{array}$

$\begin{array}{lll}6.88 & 5.11 & 7.07\end{array}$

$\begin{array}{lll}30.15 & 30.02 & 24.59\end{array}$

$\begin{array}{lll}44.77 & 44.15 & 38.51\end{array}$

$\begin{array}{lll}30.09 & 30.90 & 29.12\end{array}$

$\begin{array}{lll}28.12 & 26.47 & 19.55\end{array}$

$\begin{array}{lll}10.91 & 16.88 & 10.97\end{array}$

$\begin{array}{lll}0.36 & -3.03 & -10.97\end{array}$

$\begin{array}{rrr}0.36 & 3.03 & 0.39 \\ 1.14 & 15.66 & 0.82\end{array}$

$\begin{array}{llr}15.33 & 20.39 & 15.95\end{array}$

$\begin{array}{lll}1.13 & 20.39 & 15.95 \\ 13.18 & 19.38 & 15.32\end{array}$ 
Table 2. Regression analysis of net external debt (1996)

The dependent variables is net external debt of the company scaled by total assets. The regressors are the logarithm of total assets which proxies the size of the company (Size), dummies that identify Operating and Financial companies, a dummy for Listed companies, the value of the cash flow share of the controlling agent (Cash Flow Share), return on investments (ROI), the share of non financial assets over total assets (NFA), and the interaction between the dummies for Operating (Financial) companies and the dummy signaling whether the company is owned with less than 100 per cent shares (Minority shareholders). All the regressions include group dummies. In parentheses are t-statistics, based on White corrected standard errors. The estimates are obtained using the "robust" option in Stata®.

\begin{tabular}{|c|c|c|c|c|c|c|c|c|}
\hline \multirow{2}{*}{$\begin{array}{l}\text { Dependent variable: net } \\
\text { external debt }\end{array}$} & \multicolumn{2}{|c|}{$\begin{array}{c}\text { All firms } \\
\text { (A) }\end{array}$} & \multicolumn{2}{|c|}{$\begin{array}{l}\text { As }(A) \text {, without groups } \\
\text { with one observation } \\
\text { (B) }\end{array}$} & \multicolumn{2}{|c|}{$\begin{array}{l}\text { As (B), excluding } \\
\text { state owned firms } \\
\text { (C) }\end{array}$} & \multicolumn{2}{|c|}{$\begin{array}{l}\text { As }(C) \text { excluding } \\
\text { financial firms }\end{array}$} \\
\hline & 0.018 & (3.19) & 0.017 & (3.26) & 0.019 & (2.71) & 0.018 & $(2.63)$ \\
\hline ROI & -0.081 & (1.95) & -0.081 & $(-1.99)$ & -0.087 & $(-1.64)$ & -0.082 & $(-1.49)$ \\
\hline NFA & 0.067 & $(1.37)$ & 0.067 & $(1.40)$ & 0.060 & $(0.90)$ & 0.032 & $(0.46)$ \\
\hline Listed & -0.073 & $(2.34)$ & -0.073 & $(-2.39)$ & -0.099 & $(-2.80)$ & -0.090 & $(-2.43)$ \\
\hline Cash Flow Share & 0.020 & $(0.27)$ & 0.020 & $(0.27)$ & -0.040 & $(-0.43)$ & -0.036 & $(-0.30)$ \\
\hline Operating & -0.090 & $(2.08)$ & -0.090 & (2.12) & -0.155 & $(-3.03)$ & -0.146 & $(-2.81)$ \\
\hline $\begin{array}{l}\text { Operating*Minority } \\
\text { shareholders }\end{array}$ & -0.014 & $(0.72)$ & -0.014 & $(-0.73)$ & 0.011 & $(0.49)$ & 0.005 & $(0.22)$ \\
\hline Financial & -0.202 & $(-2.16)$ & -0.202 & $(-2.20)$ & -0.261 & $(-2.46)$ & & \\
\hline $\begin{array}{l}\text { Financial*Minority } \\
\text { shareholders }\end{array}$ & 0.067 & $(0.66)$ & 0.068 & $(0.67)$ & 0.044 & $(0.39)$ & & \\
\hline n. observations & 728 & & 699 & & 521 & & 469 & \\
\hline $\mathrm{R} 2$ & 0.34 & & 0.25 & & 0.29 & & 0.32 & \\
\hline
\end{tabular}


Table 3. Regression analysis of net external debt (1992)

This table replicates the regression of table 2 for the year 1992, prior to the Ferruzzi insolvency.

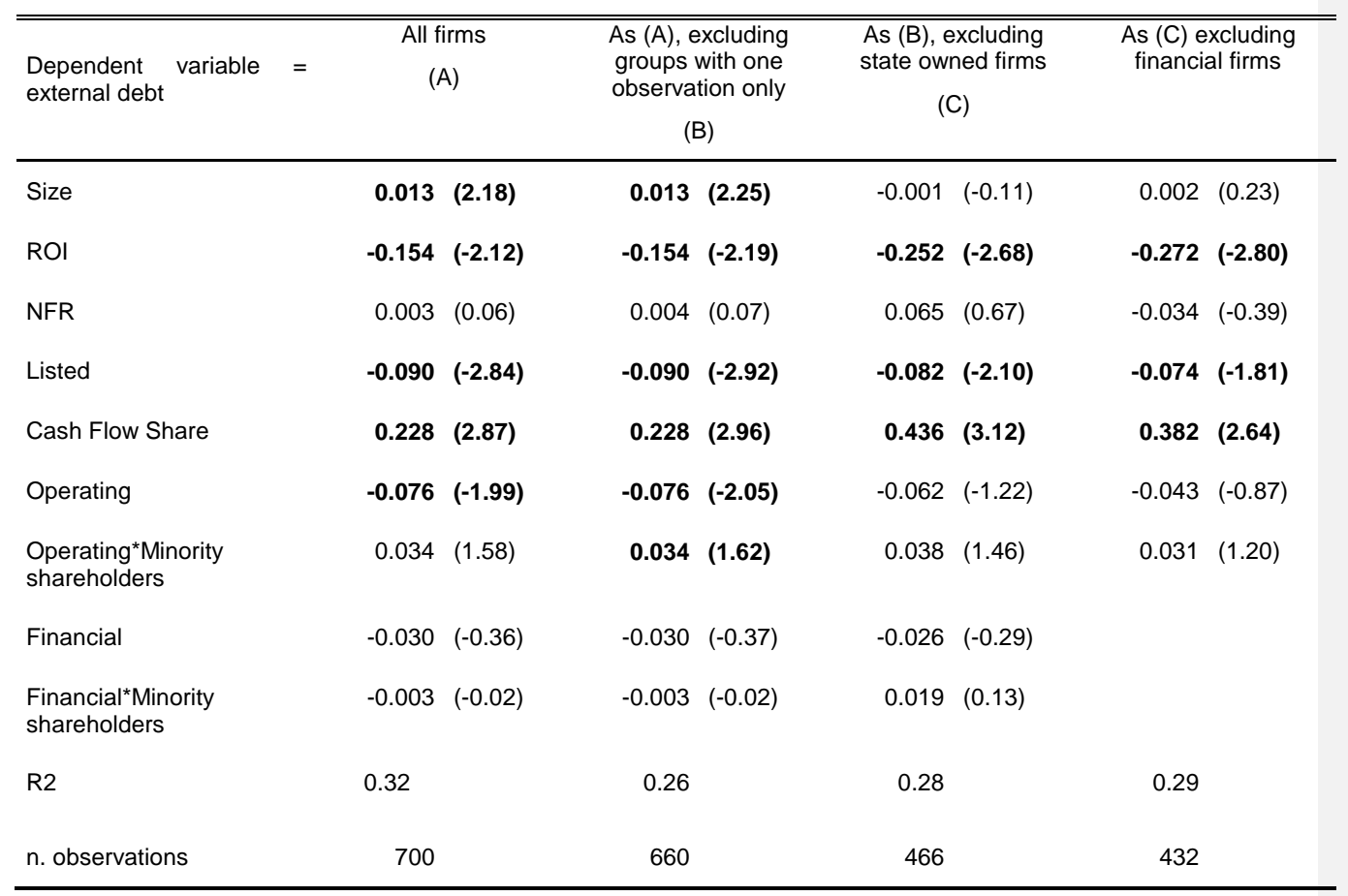


Table 4. Regression analysis with volatility (1996)

This regression replicates those in table 2, including also the standard deviation of ROI over the period 1991-95 (Volatility). Several observations are lost in computing this variable, hence the lower values of the $t$ statistics.

\begin{tabular}{|c|c|c|c|c|c|c|c|c|c|}
\hline \multirow{2}{*}{$\begin{array}{l}\text { Dependent variable: } \\
\text { external debt } \\
\text { Size }\end{array}$} & \multirow{2}{*}{ net } & \multicolumn{2}{|c|}{$\begin{array}{l}\text { All firms } \\
\text { (A) }\end{array}$} & \multicolumn{2}{|c|}{$\begin{array}{l}\text { As }(A) \text {, without groups } \\
\text { with one observation } \\
\text { (B) }\end{array}$} & \multicolumn{2}{|c|}{$\begin{array}{l}\text { As (B), excluding } \\
\text { state owned firms } \\
\text { (C) }\end{array}$} & \multicolumn{2}{|c|}{$\begin{array}{l}\text { As }(C) \text { excluding } \\
\text { financial firms }\end{array}$} \\
\hline & & 0.022 & (3.13) & 0.022 & (3.19) & 0.019 & (2.39) & 0.018 & (2.31) \\
\hline ROI & & -0.132 & $(-2.00)$ & -0.132 & $(-2.04)$ & -0.139 & $(-1.64)$ & -0.147 & $(-1.74)$ \\
\hline NFA & & 0.039 & $(0.85)$ & 0.040 & $(0.87)$ & -0.002 & $(-0.03)$ & -0.017 & $(-0.24)$ \\
\hline Listed & & -0.088 & $(-2.48)$ & -0.088 & $(-2.53)$ & -0.109 & $(-2.75)$ & -0.101 & $(-2.48)$ \\
\hline Cash Flow Share & & 0.041 & $(0.48)$ & 0.041 & $(0.49)$ & 0.000 & $(0.03)$ & 0.000 & $(0.03)$ \\
\hline Volatility & & 0.002 & $(1.59)$ & 0.002 & $(1.62)$ & 0.001 & $(0.52)$ & 0.001 & $(0.63)$ \\
\hline Operating & & -0.081 & $(-1.60)$ & -0.081 & $(-1.63)$ & -0.136 & $(-2.15)$ & -0.128 & $(-2.01)$ \\
\hline Operating* Minority & & 0.000 & $(0.01)$ & 0.001 & $(0.01)$ & 0.018 & $(0.69)$ & 0.015 & $(0.55)$ \\
\hline Financial & & -0.193 & $(-1.58)$ & -0.193 & $(-1.61)$ & -0.252 & $(-1.66)$ & & \\
\hline Financial* Minority & & 0.052 & $(0.37)$ & 0.052 & $(0.38)$ & 0.036 & $(0.22)$ & & \\
\hline n. observations & & 461 & & 450 & & 339 & & 315 & \\
\hline $\mathrm{R} 2$ & & 0.44 & & 0.38 & & 0.43 & & 0.42 & \\
\hline
\end{tabular}

